\title{
A Small Chinese Town Television Station's Struggle for Survival How a New Institutional Arrangement Came into Being
}

\author{
Sun Wusan \\ Journalism and Communication Institute \\ Chinese Academy of Social Sciences (CASS), \\ Beijing, China
}

Keywords: $\quad$ Local Government, Chinese Television, Institutional Transformation

\begin{abstract}
This paper presents a study of a town television station in north China carried out in May 2003. In the case study area, a conflict occurred between the city Broadcasting and Television Bureau and the town government over who had the right to supervise the town television station. Both sides mobilized their political resources in the fight, but in the end the town government prevailed and controlled the administrative rights. Consequently, the institutional arrangement of the central government came to nothing. This paper explores the multiple conflicts of interest embedded in Chinese television sector as it moves towards a more decentralized system. While previous scholarship has maintained that the institutional transformation of Chinese broadcasting is guided by the central government, this paper's main argument is that, in fact, local governments at different levels have controlled such transformations and manipulated tensions in the market according to their own interests. Fundamental changes in the relationship between the central and local governments have led to the latter gaining more power in determining the outcomes of broadcasting
\end{abstract}

\section{Introduction $^{1}$}

A dominant trend among academics concerned with the institutional transformation of the Chinese media is to focus on the policy of China's four tiered broadcasting system, the integration of television and cable, and media conglomeration (Guo 2003; Hu 2003; Zhao and Guo 2005; Lu 2001) and how these have been guided by the Chinese government's central administration. Therationality of the transformation and its consequences have been reviewed and solutions suggested. However, China's broadcasting system is not a homogeneous entity but a complex system with multiple interests. While power still emanates from the centre, local governments try to exert significant influence on the institutional arrangements of Chinese broadcasting. Such efforts at various times result in rectification of an order, or a new policy altogether.

Westminster Papers in Communication and Culture (C) 2006 (University of Westminster, London), Vol. 3(1): 42-57. ISSN 1744-6708 (Print); 1744-6716 (Online) 
In 1997, with the reorganization of the broadcasting system, the central government modified the four-tiered system in an effort to rein in the overexpansion of local broadcasting. As a result, more than two thirds of broadcasting entities were merged or closed. In 1999, a new policy aimed to control county television stations by restricting their broadcasting of locally produced programming to two hours per day. All other broadcasting was required to transmit central and provincial programming. Such a recentralized policy was boycotted by county television stations since they viewed it as potentially leading to their demise. No television stations in the current study had implemented the policy, and provincial and prefectural broadcasting bureaus never sought to enforce the policy, which led to its being retracted after three years.

After China joined the WTO, a policy of media conglomeration was implemented in order to compete with foreign broadcasting companies. Twenty broadcasting groups were established within three years, but this process was stopped by the State Administration of Radio, Film, and Television (SARFT) in 2003. The main reason for the failure of this policy was that local institutions did not view placement into such groups as meeting their interests (Hu 2003). I attribute the rapid change of TV institutional arrangement to either a mistake in decision making by the central government or the result of abuse, variation or boycott by the local. The central government's analysis of the operation and transformation of the broadcasting system was insufficient because it failed to consider local conditions. In this study, I attempt to discuss the institutional changes in Chinese television through examining how, in the context of decentralization, local governments receive and rework the institutional implements emanating from the power centre in accordance with their own needs and interests.

I explore the complicated power grid of Chinese broadcasting at the local level, drawing upon research carried out in a town located in north China from 2003$2005^{2}$. The study examines how a local government made a favorable arrangement for itself when it met an adverse institution. Drawing on Foucaultian notions of power, my analysis begins by observing practical power relationships at the local level. According to Foucault, a study about power that begins with an institution can fall into defending the institution, or explaining power by power itself, or exaggerating the privilege of one side in a power relation. Foucault suggests that to analyze institutions one must begin with their power relations that exist only within an exercise of power (1982). To Foucault, power is something that circulates and that is not fixed; it is not an institution, not a structure; rather power 'is the name one attributes to a complex strategic relationship in a particular society' (Foucault 2002, 121). The dominant effect of power depends on its dispatching, scheme, tactic, technology and operation (Foucault 1999a, 28) As such, Foucault's strategy of beginning with an absolutely realistic and practical notion of power for a study 
of institutions (Foucault 1999b) aligns with my analysis of the complex relationship of power in local television stations in China.

\section{Decentralization and Four Tiers Television System}

In order to rebuild the political, economic and social order destroyed by the Cultural Revolution between 1966 and 1976, Deng Xiaoping proposed transferring economic power to local levels at the end of the 1970s. He hoped this would increase the enthusiasm of both state and local enterprises as well as individuals for his economic development (Lin 2000). Decentralization has now lasted more than twenty years and has become the most important tenet of administrative reform in China (Mao 2003; Lin 2000). Decentralization started with the contract system, which replaced the centralized income and expenditure system and made the government at each level responsible for its own fiscal surplus or deficit. ${ }^{3}$ Local governments thus became economic organizations with separate interests and the right to deploy their own resources as they saw fit (Yang 2000). While this policy motivated local governments, it also created conflicts between the central and the local. Local governments were put in the dubious position of having to at least appear to adhere to the policies and authority of the central government while representing local interests. The same conflict appears among local administrations at different levels.

Decentralization was also implemented in the broadcasting system. In 1983, a four-tiered TV system was put forward by the central government to encourage local governments to establish TV stations. This policy was implemented because of a shortage of capital on the part of the central government. Its main components were: 1) in addition to central and provincial governments, prefectures and cities/counties were also permitted to invest in television stations in their jurisdictions, 2) a local Broadcasting and Television Bureau (BTB) would be required to supervise the TV station. It would be an agent of the central government at the local level as well as an operator of the local TV station. Administratively, BTBs are subordinated to the local government but directed by the central government administration.

For the central government, this is an ideal structure because local governments must pay for television stations and BTBs, but the central government holds all decision-making power. However, as mentioned earlier, in reality those institutional arrangements of the central government that have not been viewed as favorable from a local perspective have not been enforced, even though a management system from top to bottom was developed. The roles of the central and local governments in the local broadcasting system as well as which entity is the final decision-maker for local broadcasting institutions are not as clear cut as they might appear. 
In what follows, I will first provide a background of Whitecanal town and its Whitecanal Television (WTV) and the relationship of the town government with Highstele city BTB. I will then discuss a few examples of the administrative power of the town TV station to show the roles of local governments at different levels in the event.

This case displays clearly the conflicts between the local government and the institution of the power centre. It also reveals the tactic for conflict settlement used by the local government.

\section{Whitecanal Town and its TV Station}

Whitecanal is a township under the jurisdiction of Highstele city. It has an area of 12 square kilometers and a population of 40,000 , including the migrant population in the town and the rural population. In the early 1990s when the nation was fervently developing small towns, it was listed as a 'pilot town for the national integrated reform' because it was rapidly getting rich. People's Daily, a newspaper of the Central Committee of the Party, and the Guangming Daily, a newspaper of the State Council, both carried special reports on the development of this town, and in 2002, it was designated by the United Nations as a 'Pilot Town for Sustainable Development'. Its revenue was half of Highstele city for a time.

Town governments are at the lowest level of the administrative system, and are not to be permitted to have a TV station or create programming. They can have a relay station but with no right of supervision.

However, in 1992, the provincial government suggested that Whitecanal establish a television station. The town government then invested in equipment, but because of political and economic disturbances, the station was not able to start broadcasting until 1996 when WTV went on air.

\section{City Bureau: 'Why Should I Respond to Him?'}

When Whitecanal town initially planned the operation of the television station, it won strong support from the Party committee and government of Highstele city. Highstele BTB was also enthusiastic because the television station had the financial support of the town government and did not need a cent from the bureau. Additionally, the city bureau believed it was the natural industry presiding over the town television station and wanted to claim the operation of the television station as one of its achievements in widening television coverage in rural areas. According to the No. 119 Document (1997) of the SARFT ${ }^{4}$, radio, television and cable television stations established in the same county should be incorporated into one entity, over which the County BTB should exercise unified leadership and administration of institutional setup and growth, personnel, and operational 
earnings. Moreover, the town television stations themselves were to be part of the city station entity. In contrast, local governments were investing millions of yuan and manpower in order to 'effectively develop the local economy and safeguard and represent the local interests' as well as to 'win strong support and high authority in a locality' (Zhao 2000). For the government of Whitecanal town, the direct intention of establishing a television station was to let the local public see, through television, the town government's role in developing the local economy and to strengthen administration over town society. It was not intended to add something to the achievements of the Highstele BTB or the prefecture bureau or even the provincial bureau that was in charge of radio and television, nor was it to enlarge the coverage area of the central and provincial government television stations. As one Whitecanal official noted, the town 'urgently needed a bridge or medium for the Party committee and government to communicate with the grassroots people, villages, community, businesses and markets'. (Shang interview, $13 / 02 / 2004)$

Furthermore, from an economic perspective, Whitecanal town did not want to turn its own investment into an asset of the city bureau of radio and television, nor did it want to be forced to share benefits and thus increase its own operating costs with the city bureau simply because of the latter's intervention. More importantly, refusing to accept the jurisdiction of the city bureau meant the town station could compete with it on an equal footing for the market of Highstele city. As Yang, the secretary of the town Party committee then observed, WTV was the business of the town government (Huang interview, 14/04/2004). For the city bureau to represent the industry's administrative system and exercise management control over WTV would be irrational. As a deputy secretary of the city Party committee and secretary of the town Party committee, he felt he was competent to lead a television station without the interference of the city bureau. As he rhetorically asked about Li, the chief of city BTB, 'Who does he think he is? Why should I respond to him? ...What's the point talking to him? Why should he meddle?' (Huang interview, 14/04/2004).

Instead, Yang proposed that the WTV be led by the town government rather than the city BTB. However, the city bureau categorically disagreed and refused to approve the application from the town government to establish a television station and to report it to a higher authority. But the town government had rich political resources in the city. According to Shang, 'Our position [Whitecanal town] is unique. In most cases, the Party secretary of Whitecanal town has always been a member of the standing committee of the city Party committee, or concurrently a deputy secretary (of the city Party committee). The city bureau of radio and television can do nothing about it'. (Shang interview, 13/02/2004) 
Yet the city Party committee supported Whitecanal town for deeper reasons. Firstly, Whitecanal was a former national model town and as a result used to functioning as an important symbolic capital of Highstele city. Second, the television station of Whitecanal was the first town television station of that province, and its success or failure was not only related to the political performance of the city government but was also vital for its own rejuvenation. Thirdly, the Party secretary of Whitecanal was also the deputy secretary of the city Party committee and was at the heart of the political power of Highstele city. He possessed more political resources than the city bureau of radio and television and played a key role in convincing the city Party committee and city government. Fourth, the economic strength of Whitecanal town supported its political position. At that time, Whitecanal accounted for one-fourth of the total financial revenue of Highstele, ranking first among more than twenty towns and townships with its prosperous economy spurring economic development in neighbouring areas.

Although the city BTB was authorized by the SARFT to supervise a town TV station, local governments, whether at the province, prefecture or city/county levels, controlled local broadcasting bureaus and appointed their chiefs. This meant that both the appointment and removal of the bureau chief was in the hands of the city Party committee, and the town Party secretary just so happened to be one of the leading members of the city Party committee. So the city government's decision was the final decision for Highstele BTB. We can see that the administrative power of the town TV station couldn't be put into effect, even its modality was denied. The purpose of institution design of central government was invalid in the city.

The city bureau had no choice but to submit to the city Party committee and sign an agreement that a license could be granted to Whitecanal town television station so that it could operate legally.

\section{License Incident}

March 8, 1997 marked the official inauguration of WTV. It was also the day the station officially declared war on neighbouring television stations by competing for advertising revenues. Highlighting WTV's ambitions, Shang, the former director of WTV, noted: 'It (Whitecanal town) has a very favourable geographic position...; it is located in a golden triangle and has built a television station of its own. It could cover many cities (towns also)..., and has more advantages than Highstele city. Highstele city can only cover part of Highstele's own jurisdiction and parts of a couple of peripheral counties.' (Shang interview, 13/02/2004). 
The planned coverage area of WTV was larger than that of the television station of Highstele city, which not only meant more potential advertising revenue but also greater political influence. The head of WTV had the bold goal of becoming the second radio and television centre in Highstele city.

In the face of the challenge from Whitecanal town, city BTB could not arbitrarily add the television station of Whitecanal town as one of its affiliates, as that would be an open confrontation to the leadership of Highstele city's Party committee. But it also could not just allow the station to do whatever it wanted. Therefore, the city bureau changed its tactics and complained to the prefectural bureau of radio and television that Whitecanal town television station was in violation of broadcasting rules. As soon as the television station of Whitecanal town began operating, the prefectural bureau received one complaint after another saying the television station was operating without a license and should be shut down. According to Huang:

\begin{abstract}
In the days nearing the official inauguration of the station, all the counties ${ }^{5}$ (around Whitecanal) - X county, R county, Xi county and Highstele city complained, even to the provincial authority. They asked for intervention from Baod bureau (prefectural level) [...] The fiercest complaints came from Highstele city and R and X counties, because their advertising revenue had been eroded. The charges were illegal production of programming. (Huang interview, 14/04/2004)
\end{abstract}

In fact, it was true that when WTV began broadcasting it had no business license because the prefectural BTB had detained the town's license application in resentment at its illegal independent position. Thus, the prefectural BTB sent a deputy bureau chief to Whitecanal town to halt its WTV. In the studio, the deputy chief of the prefectural bureau and the Party secretary of Whitecanal town nearly came to blows. While the former was determined to switch off the transmitter, the latter was even more resolute, saying, 'If you dare to take away the key, I'll kick you out of the building!'(Huang interview, 14/04/2004). At last, the two compromised. The prefectural bureau agreed to let the television station of Whitecanal town continue operating before it obtained a license if it promised only to relay programs distributed by CCTV. In addition, Whitecanal town pledged to obtain the license as soon as possible so as to silence criticism from neighboring television stations.

Immediately the Party secretary of Whitecanal personally went to the provincial capital to mobilize his social connections and accelerate the licensing process. At this time, according to $\mathrm{SH}$, a leader in the Propaganda department of the provincial Party committee was fairly supportive of Whitecanal town. He felt sorry because in 1993 the town had suffered from a particularly harsh economic crackdown after it had been exposed by CCTV for trafficking guns and selling 
large numbers of pornographic CDs. As a result, the town was consolidated and the market remained sluggish for three years. Because he had been in charge of the campaign and it had ended up being too harsh, the leader of this campaign 'felt he owed something to Whitecanal town and wanted to do something for Whitecanal town.' He thus began working for the license through various connections (Shang interview, 13/02/2004). It eventually took only three days for Whitecanal town officials to persuade the industry authorities at the prefectural and provincial levels to grant them a license.

Another crucial factor in Whitecanal town's success in obtaining a license was that the town, as mentioned earlier, had been cited by the People's Daily and the Guangming Daily as a developmental model. Several top officials from the central government had gone there for inspections, and Whitecanal town had become an important symbolic capital of the provincial government. The establishment of a television station was designed to increase the significance of the Whitecanal as a model town and this was put forward at the provincial governor's working conference and documented.

Though Whitecanal was granted a license by the provincial BTB, the BTBs at provincial and prefecture level were fully aware that its independent status made it illegal. They hoped to support their colleagues, the city BTB, but they had to keep silence after the leader of the Propaganda Department of the Provincial Party Committee interceded for Whitecanal town.

The license was a like a symbolic backstage pass from the provincial BTB and the Party's Propaganda Department and there was little the city and prefectural levels could do to prevent it.

The license event shows an obvious difference between a practical and an ideal administrative power structure. Although BTBs at different levels are controlled vocationally by the central government, and acknowledge and support each other as an integrated management system, they individually are also part of local administrations. So they are not fixed to a single administrative system, instead they circulate in two interweaved power networks (Foucault 1999b). As subordinates of local governments, they have to make sure the choices they make are politically safe. When a conflict occurs between the institutional arrangements of the central government and the local rules, the latter usually trumps the former. The town government also circulated on the power network, it got its advanced strategic position. 
Fight over Cable Network

In 1998, hoping to improve the television reception of its residents and earn revenue from service fees, Whitecanal laid a cable television network that stretched to the surrounding urban areas. However, in 1999, shortly after the network was laid, the cable network of Highstele city's post office reached the neighboring town. After a careful examination of this situation, WTV knew it was in no position to maintain an isolated network that could compete with the city post office. Therefore, it sold the network to the post office with the condition that its television station signals would be able to enter the rural network of Highstele city, 'occupying one channel.' W'TV's thinking was that although it would no longer be able to collect viewing fees, its programming might become popular in the surrounding towns, townships, and even villages. In this way, W'TV's coverage would be greatly expanded, which would not only help raise advertising rates and increase earnings, but also spread the political and economic influence of Whitecanal town in the areas under the jurisdiction of Highstele city. This would truly turn the television station of Whitecanal town into the second centre of the local radio and television system. Fortunately for Whitecanal town, the negotiations with the post office went extremely smoothly, and, as hoped, WTV became the first station to broadcast using the rural network, entering all homes covered by the rural cable network of Highstele city.

Once it began operating, WTV's advertising revenue rose rapidly from 300,000 yuan in 1997 to 600,000 yuan the following year. By 1999, advertising earnings had reached 1 million yuan (Shang interview, 30/03/2005). Although WTV's signals did not reach the urban area of Highstele city and posed no direct threat to the city's television station, the city bureau found it necessary to disrupt the momentum of its development. In 2000, the city government decided to coordinate the urban and rural cable networks belonging to the bureau and the post office, respectively. City BTB seized the opportunity to take action to curb WTV's growth by making an agreement with the post office to close the front-end of the rural network, adopting instead the signal source provided by the city television station. This move cut off the signal that had enabled WTV to broadcast to the rural areas and effectively contained its expansionary momentum.

Being squeezed out of the cable network was extremely harmful to the television station of Whitecanal town. Not only was the original dream of entering all the towns and districts of Highstele city shattered, but also the residents near the headquarters of the television station were unable to receive its signal firmly. More than 2,000 households in Whitecanal had officially joined the cable network. When the number of households which had illegally entered the network was added, more than 4,000 households were connected. With the signal of WTV cut off from the network, nearly 20,000 urban residents were unable to receive the station's programming on a regular basis. This was potentially economically disastrous as 
the cable viewers comprised the main source of the town's revenue and were the targets of a government backed publicity campaign. If the situation was allowed to continue for long, advertisers would pull out, jeopardizing the survival of the station. Even though the town television station had the advantage of local transmission and its signal could sneak into the television sets in the urban district, the reception was very poor. A clear signal flowing through either the rural or the urban cable network was essential for attracting advertising revenue.

After weighing the pros and cons, the town government reluctantly decided to give in to the existing system and requested that it be incorporated into the broadcasting industry's administrative management system. In exchange, Whitecanal town officials requested a compromise on the part of the city BTB so that WTV could legally participate in the distribution of the cable television market. The town government would allow its television station to be incorporated into the management of the city bureau but would have to abandon its name and become the second station of Highstele city under the jurisdiction of the city bureau of radio and television, in addition to paying a management fee.

Due to a complex administrative system as well as strained personal relationships between the leaders of various government departments, the officials of the Highstele city bureau and Whitecanal town had always maintained a lukewarm relationship. The city bureau did not extend to the town station the policies, notices, or regulations that came from a higher bureau, did not assume responsibility for either the technical titles of the personnel of the town station or its future staff development ${ }^{6}$, and did not intervene in its finances. On the other hand, the town station did not relay the news broadcasts of the city station because the two stations were largely independent of one another. Only when a major event was held by either the city government or the government of Whitecanal would both stations broadcast simultaneously.

However, now the market forced Whitecanal town to abandon its independence and seek reconciliation with the city bureau. If the city bureau allowed the town television station to enter the system and granted it legitimacy, the town station could carve up the cable market of Highstele city. Yet the city bureau realized that if it refused, it would be unable to bring WTV under its jurisdiction. Faced with such a dilemma, the city bureau refused to negotiate unless the town station 'was taken over, managed, and staffed by the bureau in a unified way' (Sun interview, $30 / 03 / 2005)$. Such a takeover meant that the staff, finances, and equipment were all transferred to the city station without compensation. 
Commenting on this situation, the chief of the city bureau of radio and television said with perfect assurance:

This is what the state says. The higher authority says I should take care of you [WTV]. If you want me to spend money taking care of you, I will absolutely refuse to do so. I will never invest in you. Even if you want to sell this thing to me, I will not buy. I want it free. If I can have it free, I will take care of it. If I cannot have it free, I will not take care of it. (Huang interview, 14/04/2004)

Not surprisingly, Whitecanal town officials dared not, and would never hand over on a silver platter the millions of yuan worth of assets left over by their predecessors. $^{7}$ To any local Chinese government, this would be a major stain on its performance record. As Huang also noted, the officials of Whitecanal town had become accustomed to utilizing WTV as a management instrument to make announcements, publicize new policies, and display their economic or political successes. They appeared 'on television for the slightest cause.... if the government of Whitecanal town abandons its television station, it would not know how to walk.' (Huang interview, 14/04/2004)

For several years, the city bureau did not offer any possible compromise, and the two sides were forced to maintain the status quo. However, in the second half of 2004 a favourable opportunity for the television station of Whitecanal town arose when the chief of GBRT was replaced by the first head of the town television station. As the first station head, he had been responsible for manoeuvring WTV towards independence, by obtaining its business license, building and selling the cable network, and presiding over the entry of the town station into the rural network. As expected, at the outset the new bureau chief backed W'TV, stating, 'The development of Whitecanal town deserves support. It is a special zone, a pilot unit. Whoever deserves support will receive support. I will never place any obstacle in your way'. (Shang interview, 30/03/2005)

Nevertheless, participation in the cable network came with conditions attached. Incorporation into the management system of the television industry was no longer a political issue but a commercial one. The main goal of Whitecanal town was to integrate the Whitecanal town television station into the cable network of Highstele city so that Whitecanal town's programming could be transmitted to the entire city, yet financial resources were limited. As Shang said in an interview:

If the station of Whitecanal town entered this network and competed with the station of Highstele city or even covered a larger area than the station of Highstele city, then we had to consider the advertising resources. [I must consider] the livelihood of more than 200 people here. (Shang interview, $30 / 03 / 2005$ 
The bureau chief proposed that if the television station of Whitecanal town intended to enter the network, it had to pay 500,000 yuan per year to the city station as compensation for its lost market share. The negotiations faced a dilemma once more, but to Whitecanal town the true meaning lay in the fact that the city bureau no longer regarded Whitecanal town as a political rival but instead recognized its market status. Although entry into the system remained a bone of contention between the two sides, it had also become a bargaining chip.

After several months of discussion, in 2005 Whitecanal town television station abruptly ended the negotiations, for the town had found another way out. In order to solve the instability of the cable signals in the urban area, WTV had contacted the post office that owned the rural network. In the course of these contacts, Whitecanal town discovered that the post office was willing to cooperate with Whitecanal town in improving and developing the limited rural network. Negotiations began between Whitecanal town and the post office, and the two sides agreed that Whitecanal town could use administrative means and even the police when necessary to help the rural network combat the problem of illegal network use. In return, the rural network would allow WTV to set up a local forwarding machine for broadcasting its programming. The two sides also discussed the possibilities of profit sharing and joint investment in improving the whole rural network. (Sun interview, 30/03/2005) In the short term, the agreement allowed WTV's programs to be broadcast to the entire town cable network and offered the potential for them to enter the whole rural cable network of Highstele city.

Once Highstele city learned of the outflanking tactics used by Whitecanal town, the city BTB adopted a wait and see attitude. The bureau knew that it was illegal for Whitecanal to set up a cable television broadcasting forward machine and that the cooperation between the post office and Whitecanal town violated the agreement the post office had signed earlier with the bureau. Still, as advertising resources were mainly generated in the urban area of Highstele city, at this time the cooperation between Whitecanal town and the rural network posed no serious threat to Highstele city. In addition, Whitecanal town limited its signal only to the town itself and did not encroach upon the traditional domain of the city bureau of radio and television. More importantly, based on its own experience through years of cooperating with the rural network, the bureau knew that the cooperation between Whitecanal town and the post office would be difficult to develop and posed no threat to the city station either then or in the future. Meanwhile, the city BTB had started moving toward digital cable radio and television, which offers a better signal and can be more easily managed. At the time of writing, the bureau has already applied for the first and possibly only digital channel in the area north of Baodi prefecture and plans to control the digital market in the region. Whitecanal town cannot compete with the city bureau in this new digital market. 
Along with technical and market changes, new opportunities for profit came forth, so the institutional balance was broken. The situation reversed. In the past, the town government had believed that the town could compete with Highstele's TV station either politically or financially. That was the reason it refused to be constrained by the city BTB. Now, however, it had to request to be a branch in order to extricate itself from a financial predicament. In the past, the city BTB had demanded the administrative power over the town TV station as a local agency of central power, but it later discarded that role and refused to be the town TV's leader for monopolizing the market. Their roles in the administrative system were no longer important to either of them. They adapted to the current situation, or exchanged for commercial opportunity.

Market force supported or strengthened the antagonism within the administration system and mixed with administrative power. It made the power structure of administration vaguer, or, I should say, more complex.

\section{Conclusion}

Previous studies about institutional transformations in China's television system have used the existing administrative system as a starting point for a critique of the system's irrationality, as a locus point to examine conflicts, and as a way to analyze solutions as they evolve within the existing system. This method ignores the indivisible relationship between local governments and local BTBs, as well as the way the BTBs have been deeply integrated into local interests groups. It also underestimates the depth of interventions on the part of local governments to the broadcasting system.

As my case study of the power relation between Whitecanal town and Highstele city BTB shows, the Chinese broadcasting system does not work as an administrative pyramid or as a unified whole. Dispute and conflict take place at every corner. To refer once again to Foucault, there is an unstable centre, uncounted points of collision, and conflicts and struggle arise at every point. Even relationships of power reverse temporarily (Foucault 1999a). As mentioned above, in this case, the town TV station withdrew from the system, and some county government officials' connived with the towns in their jurisdiction to have their own TV station without a license. A file published by the SARFT announced that 22 TV stations were closed in one county in Anhui province for illegal operation. The universality and diversity of conflict reveal that local governments, operating with relative financial independence gained from decentralization, are looking after their right of autonomy in various ways. 
Local governments will not reject the institutional arrangements of the central government as a whole, but instead exercise power strategically on one or part of a specific institution for a specific or immediate aim. Their strategies may join together, stimulate each other, and might turn to be new driving forces for further change. During this process, a local institution may come into being. The independence of Whitecanal TV station began with the town government's effort to withdraw from the BTB, and it was affirmed by the city BTB's refusal to take it over. Each side had its own goal. However, the town TV station was eventually legalized because of the multiple tactics employed by both sides.

In addition to the conflict between the central and local government, the local BTB had its own considerations. As an operator of a local TV station, it was forced to make a decision between its special interest and the general interest as an agency of central government. We saw that Highstele city BTB made an independent decision by refusing Whitecanal's suggestion with no pressure from local government. What made it to do so was the market.

Whitecanal town was at the bottom of the administrative system, and the town TV station was at the bottom of the broadcasting system. The town showed a pursuit for political and commercial interests so unadorned that the real power structure in the broadcasting system appeared clearly. It is not possible to conclude that an irreversible disintegration has taken place from the bottom up through an analysis of events in Whitecanal town, but similar cases can be found throughout the Chinese broadcasting system, although they might be addressed in different ways.

\section{Notes}

${ }^{1}$ I would like thank Professor Shen Yuan of Tsinghua University. He gave me many helps on this research and contributed his deep thought to this paper. Professor Colin Sparks discussed principle of this paper with me, thanks for his help. I also get help from Dr. Cara Wallis and Dr. Janice M. Engsberg, they gave me some valuable advices and polished my English as well.

2 Township is an administrative area with a government organization under county/city's jurisdiction. Its administrative head is appointed by county administration and its own jurisdiction will cover a town and a few villages. That is the lowest level of government in China.

3 According to the centralized income and expenditure system, local governments handed all of their income over to the central government, which then allotted resources for local public commodities and industries. The fiscal responsibility system divided the scope of income and expenditure between the local and central governments according to relation of administrative subjection. Local government decided their own expenditure by what it received. 
${ }^{4}$ Notice on the Implementation of the Plan of the Offices of the Party Central Committee and the State Council on Strengthening the Administration of Press, Publication, Radio and Television. Document No. G.F.Sh. Zi $(1997,119)$.

${ }^{5}$ All the counties mentioned here are those that surround Whitecanal town but are not under Stele city's jurisdiction.

${ }^{6}$ Technical titles of a personnel working in a town broadcasting system are the responsibility of stations at county/city levels. The title will determine staff's professional occupation and salary.

The heads of townships change very often. Some have terms of only a few months.

\section{References}

Foucault, M. (1982) 'The Subject and Power', in H. Dreyfus (ed.) Michel Foucault: Beyond Structuralism and Hermeneutics, Chicago: University of Chicago Press, pp. 208-226.

(1999a) Discipline and Punishment: The Birth of the Prison, (Guixun yu Chengjie: Jianyu de Dansheng), Beijing: Sanlian Book Store (in Chinese). (1999b) Il Faut Defendre La Societe, Shanghai: Century Publishing Group (in Chinese)

(2002) Histoire de la Sexualitié, Shanghai: Century Publishing Group.

Guo, Z. Z. (2003) 'Playing the Game by the Rule? Television Regulation around China's Entry into WTO', Javnost-The Public, 10(4): 5-18.

$\mathrm{Hu}, \mathrm{Z} . \mathrm{R}$. (2003) 'The Post-WTO Restructuring of the Chinese Media Industries and the Consequences of Capitalisation', Javnost-The Public, 10(4): 19-36.

Lin, S. L. (2000) 'Power and Institution. A Practical Logic of Chinese Politics', (Quanli yu Tizhi: Zhongguo Zhengzhi Fazhen de Xianshi Luoji) available at http://lovelyguy.51.net/articles/ccclslql.htm (accessed 17/10/ 2002).

Mao, S. L. (2003) 'The Past and Future: Institution Reform of Chinese Government', (Zhongguo Zhengfu Tizhi Gaige de Guoqu yu Weilai) available at http://www.wiapp.org/wpapers/wpaper200312.html (accessed $19 / 12 / 2003)$.

Yang, R. L. (2000) 'A Diffusing Way in Middle of Institutional Transformation and Innovation of Local Government: Case Studies about Institutional Transformation in China, Chinese Finance and Economics Press, 2: 353-378 (in Chinese).

Zhao, C. G. (2000) 'Central and Local during Transformation', Strategy and Management, 40(3): 44-51 (in Chinese).

Zhao, Y. Z. and Z. Z. Guo (2005) 'Chinese Television: History, Political Economics and Ideology' in J. Wasko (ed.) A Companion to Televisions, Malden, MA: Blackwell Publishing. 
Sun, A Small Chinese Town Television Station's Struggle for Survival...

\section{Interview Record}

Sun, Deputy Director of WTV, 30/03/2005

Shang, Director of Highstele city BTB (also first director of WTV), 13/02/2004

Shang, 30/03/2005 (information on the position held by the interviewee is confidential)

Huang, Engineer for both WTV and Highstele TV (he is also an investor of WTV), 14/04/2004 